\title{
PAP NORBERT: TÖRÉSVONALAK DÉL-EURÓPÁBAN
}

\author{
(PTE TTK FI Kelet-Mediterrán és Balkán Tanulmányok \\ Központja, Pécs, 2001, 183 o.)
}

\section{VÉGH ANDOR}

A politikai, történeti földrajzi témájú könyv a Pécsi Tudományegyetem földrajzi kutatómúhelyét geopolitikai, geostratégiai oldaláról mutatja be. A hasonló jellegü kutatások nem új keletüek az intézményben, ugyanis már 1997-ben megjelent az (akkor még a JPTE, Társadalomföldrajzi és Urbanisztikai Tanszékének kiadásában) „Európa politikai földrajza" címủ könyv, amely a rendszerváltozást követően jelentős mérföldkőnek is tekinthető a hosszú időn keresztül mellözött tudományágban, különösen annak oktatásában. Ezek mellett megemlítendỏ Pécs egyetemének számos volt és jelenlegi kutatója (Szabó Pál Zoltán, Prinz Gyula, Tóth József, Hajdú Zoltán), akik a politikum és a geográfia fogalmát ötvözve hagyományt igyekeztek teremteni a történeti, politikai földrajzi kutatásoknak.

A mủ által vizsgált téma az Európa problémakörbe illeszthetö bele, ezen belül is a Mediterráneum mint térkategória mibenlétével, külső és belső lehatárolásával, tagoltságával foglalkozik kiemelten. A szerző forrásait tekintve elsósorban az angolszász irodalomra és módszereire támaszkodik, különös hangsúlyt helyezve a Hartshorne-modellre, melyet nemcsak felhasznál, hanem továbbépíti, aktualizálja annak 1983-as alapjait, kibóvítve az államterületre ható centripetális és centrifugális erók körét.

A könyv három nagyobb gondolati egységét lehetne meghatározni. Az elsô rész általános történeti földrajzi bevezetó jellegú, amely Európa és az európaiság történetileg változó tér és geopolitika függő fogalmával ismertet meg, és vezet át a törésvonalak, korridorok problematikáján keresztül a második gondolati egységhez.

Ez a rész a mediterrán, földközi tengeri Európa geostratégia történeti és jelenkori problematikájával, szerepével, értékelésével, megfogalmazásával foglalkozó egység, amely elsősorban katonai és stratégiai szempontból elemzi a térséget, de nem nélkülözve a geográfia és a történettudomány módszereit (gazdaságtörténet, államelmélet, gazdaságföldrajz).

A multidiszciplináris megközelítés, elemzö módszer igazán a harmadik egységben, a konkrét ország-esettanulmányok esetében van jelen.

A három ország elemzése meglehetősen különbözik. Ez az egyik következménye az adott ország problematikájához rendelt vizsgálati módszerkülönbségnek, amely a három nagyító alá vett ország összehasonlítását teszi nehezebbé, viszont alaposabb betekintést és elmélyülést eredményez az adott államterek önálló elemzésébe. 
Olaszország problematikájának boncolgatása elsősorban gazdasági, történeti, politikai és közigazgatási alapokon történik. Ez az esettanulmány sikerült a legkerekebbre, részben a törésvonal problematika iskolapélda értékéböl fakadóan, de ezzel együtt dicséretre méltó e vezérfonal ötvözése a történeti, államterületi majd államszervezeti vizsgálódások szintjén.

Málta elemzése, amely a recenzens véleménye szerint legkevésbé törésvonalkoncentrált esettanulmány, elsösorban természet és társadalomföldrajzi, geostratégiai vizsgálat. Sajnos az Olaszországra jellemzó céltudatos problematikacentrikus elemzésnek itt egy hosszabb bevezetô utáni rövid fejezet felel csak meg. Így a centrifugális és centripetális erők menti eszmefuttatások pusztán három oldalra szükülnek (117-1 19. o.).

Törökország megközelítése történeti és kisebbségföldrajzi, politikai és geostratégiai alapokon történik. Erre a tanulmányra is az Olaszországéhoz hasonló komplex és alapos vizsgálat a jellemzö, azonban ez esetben nem történik meg a regionális jellegủ politikai és társadalmi szint vizsgálata, csak néhány mondat erejéig, valamint a kisebbségi autonómia kérdését felvetöleg.

Elmarad a három ország, a három törésvonal összehasonlítása is, de ennek szükségessége nem feltétlenül indokolt a már említett módszertani különbségek miatt.

A törésvonalak problematikája a cím alapján is bövebben kívánkozna elö, bár a szépen végigvezetett Dél-Európa történeti-földrajzi fejlödésvázlata címü rész (59-66. o.) után a jelenkori politikai földrajzi vizsgálódás is helyet kap (Az állami szint politikai földrajzi problémái Dél-Európában, 67-75. o.), a törésvonal és korridor problematika azonban itt sem kellöen hangsúlyos. Az elöbb említett hiány nem merülne fel, ha az országtanulmányok lefednék a teljes dél-európai térséget, így azonban remélhetjük csak, hogy a kötet folytatása nem marad el, amelyben a többi ország is hasonló elemzés tárgyát képezi.

A könyv sikeresen ötvőzi az olvashatóság, a tudományosság és az ismeretterjesztés fontosabb erényeit fejezetenként eltérö arányban, oly módon, hogy a tudomány szigorú vezérfonalát sehol sem veszíti el. 